\title{
DESIGN OF A MONITORING SYSTEM APPLIED TO SOLAR PUBLIC LIGHTING POLES
}

\section{SERGIO VILLAVICENCIO, OMAR ILLESCA, EDILBERTO CALCINA, ABILIO CUZCANO, JESSICA MEZA, WILVER AUCCAHUASI, JUAN GRADOS}

Unidad de Posgrado de la FIEE, Universidad Nacional del Callao, Lima, Perú

\begin{abstract}
This work shows a design that allows remote monitoring of sensory parameters such as solar position, luminosity, vibrations, voltages and currents in solar street lighting poles. In the development of the design of this research, the public lighting poles will have LED lighting, an energy accumulator that will be charged with photovoltaic panels that have a solar tracking mechanism dimensioned to measurements, which were calculated for a specific study area " District of Parcona - ICA ". A custom controller was designed that allows us to collect information from the sensory parameters from a distance using XBEE technology for later visualization and storage in a graphical interface developed in LabVIEW software. In this monitoring interface an autonomous control is carried out, observing in the simulations the behavior of our system both in the day mode (Charging of the energy accumulators, solar panel - battery) and the night mode (discharge of the accumulator, battery - lantern led), obtaining amperage, voltage and power values of the system for optimal operation of public lighting poles.

KEYWORDS: Monitoring, Sensory, XBEE Technology
\end{abstract}

Received: Jun 08, 2020; Accepted: Jun 28, 2020; Published: Sep 26, 2020; Paper Id.: IJMPERDJUN20201442

\section{INTRODUCTION}

Currently, solar radiation is one of the virtually inexhaustible sources of ecological energy [2], it can be transformed into electrical energy through photovoltaic panels whose efficient application can meet the demand for electricity supply in public lighting in urban and rural areas.

This research is focused on the development of a remote monitoring system that will be applied to public lighting poles with photovoltaic panels added with a one degree of freedom solar tracking system. The system will be remotely monitored by obtaining information from sensors, which allow adjustments to be made in the control of the system, improving performance in its operation.

\section{METHODS \& MATERIALS}

A design based on a 30W LED lantern will be made, therefore, we will use a $65 \mathrm{Ah} 12 \mathrm{~V}$ deep cycle dry battery, a $150 \mathrm{~W}$ photovoltaic panel that will have a solar tracking sensor that will allow us to position with the highest intensity of radiation from the sun having at the base a linear electric articulator allowing a 1 GL movement. The photovoltaic panel also has a motion sensor, an accelerometer with which we will determine its position in time.

A 20A solar regulator and charger will be used, which has a voltage and charge current control. The design of a custom controller based on a PIC18F4550 microcontroller and an XBEE transmitter will be carried out, 
which will help us to carry out an autonomous control of the system and send the information from the sensors to a data reception stage that can be processed and visualized in a graphical interface in LabView.

\section{System Diagrams}

Our diagram of public lighting with monitoring based on solar panels is represented in figure 1, representatively indicates the characteristics of its composition.

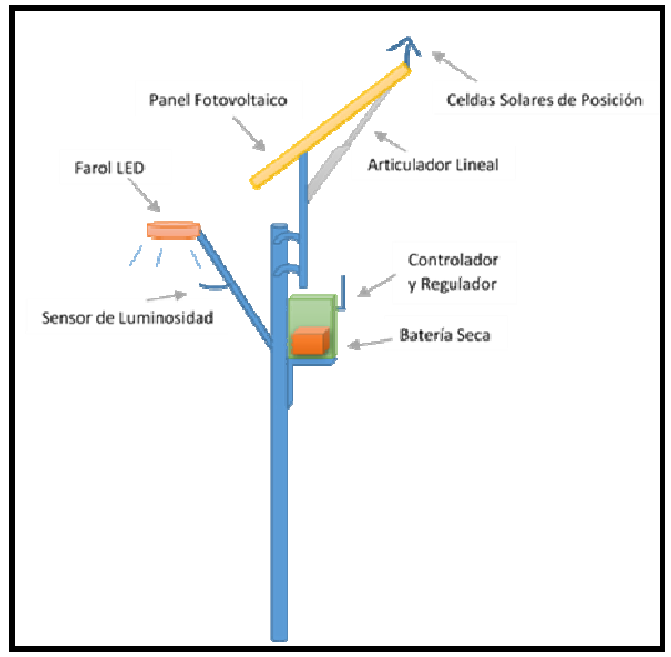

Figure 1: General System Diagram.

In figure 2 we represent the solar charger regulator the respective connections and the sensor to be used for monitoring.

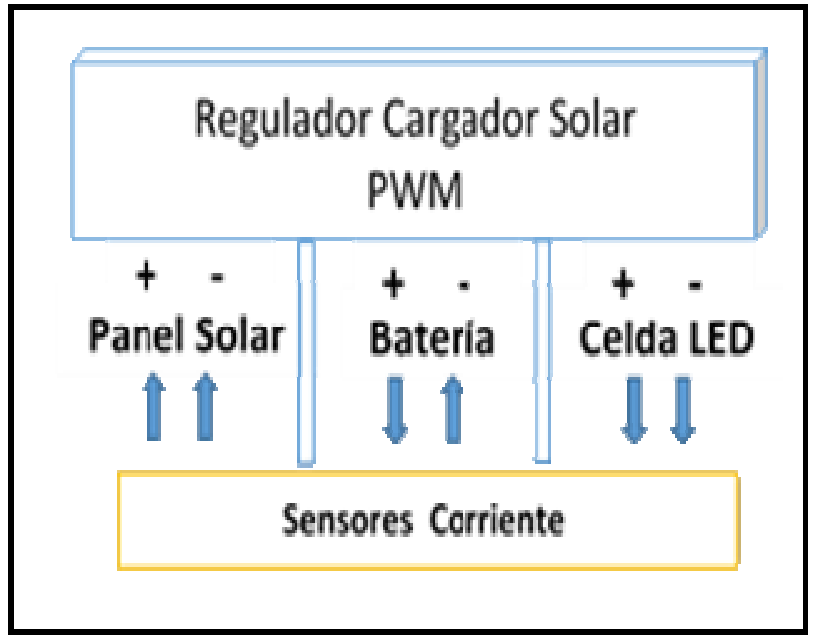

Figure 2: Solar Charger Regulator Diagram.

In figure 3 we represent the block diagram of the custom controller, using a microcontroller that allows us to govern the sensors, the transmitter and power drives that control the light intensity of the LED lanterns and the speed with which the linear actuator is going to operate. displace. 


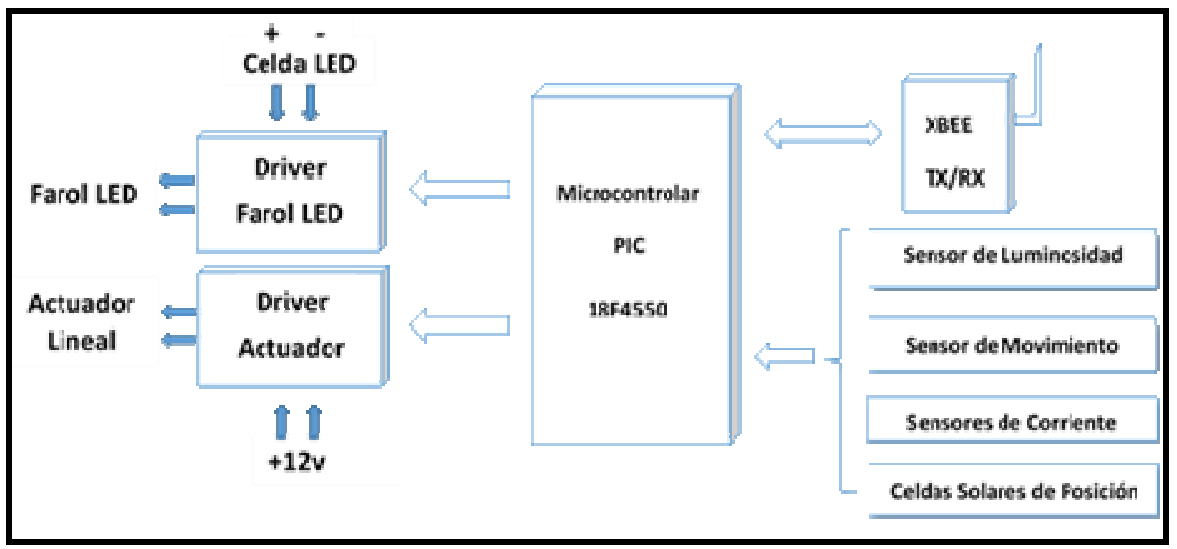

Figure 3: Custom Controller Block Diagram.

\section{Process Control}

The orientation of the panel will be activated by a linear actuator which has a power stage, which will allow speed control, which will be continuously monitored by a motion sensor, which in turn will be the feedback element for the system. closed loop.

The intensity of the LED lantern is carried out through a second power stage, which allows the brightness to be varied according to the requirement, being monitored by a lumen depression sensor over time. Thus, the process is more efficient. Below is a block diagram for process control in figure 4.

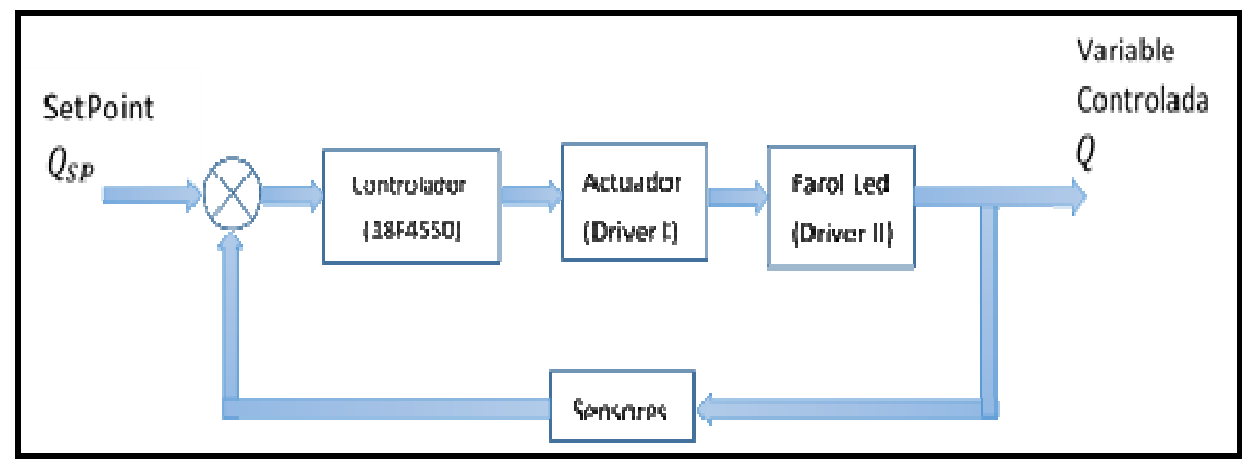

Figure 4: Block Diagram for Process Control.

\section{System Design}

\section{Estimation of Energy Consumption}

For our prototype of public lighting based on solar panels, the following DC charges are taken into account according to the figure 5 .

\begin{tabular}{|c|c|c|c|c|c|}
\hline Unidades & Carga (DC) & $\begin{array}{c}\text { Potencia } \\
\text { Unitaria } \\
\text { (Watt) }\end{array}$ & $\begin{array}{c}\text { Horas de } \\
\text { Funcionamiento } \\
\text { al Dia (Horas) }\end{array}$ & $\begin{array}{c}\text { Total Energia } \\
\text { (Wh) }\end{array}$ & $\begin{array}{c}\text { Total Energia (Wh) } x \\
20 \% \text { Margen de } \\
\text { Seguridad }\end{array}$ \\
\hline 01 & Farol Led & $30 \mathrm{~W}$ & 12 Horas & $360 \mathrm{Wh}$ & $432 \mathrm{Wh}$ \\
\hline 01 & Actuador Lineal & $18 \mathrm{~W}$ & 01 Hora & $18 \mathrm{Wh}$ & $21.6 \mathrm{Wh}$ \\
\hline 01 & $\begin{array}{c}\text { Otros (Sensores, C.I. y } \\
\text { Potencia) }\end{array}$ & $3 W$ & 24 Horas & $72 \mathrm{Wh}$ & $86.4 \mathrm{Wh}$ \\
\hline
\end{tabular}

Figure 5: Energy Consumption. 
With the data we obtain the average daily consumption of the installation to which $20 \%$ has been applied as a recommended safety margin. We must also bear in mind that in the installation there will be losses due to battery performance and this influences the final energy required. For sizing calculation purposes, we will take a battery performance of $95 \%$ and of the conductors $100 \%$ [4].

Calculation of average daily consumption $\left(L_{m d}\right)$ we consider the following expression.

$$
L_{m d}=\frac{L_{m d, D C}+\frac{L_{m d, A C}}{n_{i n v}}}{n_{\text {bat }} * n_{\text {con }}}
$$

Being $\left(L_{m d}\right)$ the average daily energy consumption, $\left(L_{m d_{1} D C}\right)$ the average daily energy consumption of continuous loads and ( $L_{m a, A C}$ ) the one of the loads in alternating (In our design it does not have alternating loads $L_{m a, A C}=0$ ).

$$
\begin{aligned}
& L_{m d}=\frac{L_{m d . D C}+\frac{L_{m d, A C}}{n_{i n v}}}{n_{\text {bat }} * n_{c o n}}=\frac{540+\frac{0}{0.90}}{0.95 * 1} \\
& L_{m d}=568.42 \mathrm{Wh} / \text { día }
\end{aligned}
$$

Calculation of the average energy consumption in Ah / day:

$$
Q_{A h}=\frac{L_{m d}}{V_{B A T}}=47.37 \mathrm{Ah} / \text { día }
$$

It is determined that the real average daily consumption is slightly higher than the nominal one, because as mentioned, we have taken into account the losses that may occur in some of the elements of the installation and the safety margin of $20 \%$.

Calculation of total annual consumption (LT) and a half yearly $\left(L_{m a}\right)$ :

$$
\begin{aligned}
& \mathrm{LT}=L_{m d} * 365 \text { días }=207473.3 \mathrm{Wh} / \text { año } \\
& L_{m a}=\mathrm{LT} / 365=568.42 \mathrm{Wh} / \text { día }
\end{aligned}
$$

In this case the average annual consumption $\left(L_{m a}\right)$ coincides with the Average daily consumption $\left(L_{m d}\right)$, since the consumption that has been estimated is constant throughout the year.

For purposes of design calculations Considering the location of the Parcona District with the coordinates Latitude -14.055 and Longitude -75.7, we obtain the solar radiation for each month according to the clean energy management software "RETScreen" developed by the Government of Canada in collaboration with NASA's Langley Research Center which collects scientific data from Earth. [3]. 


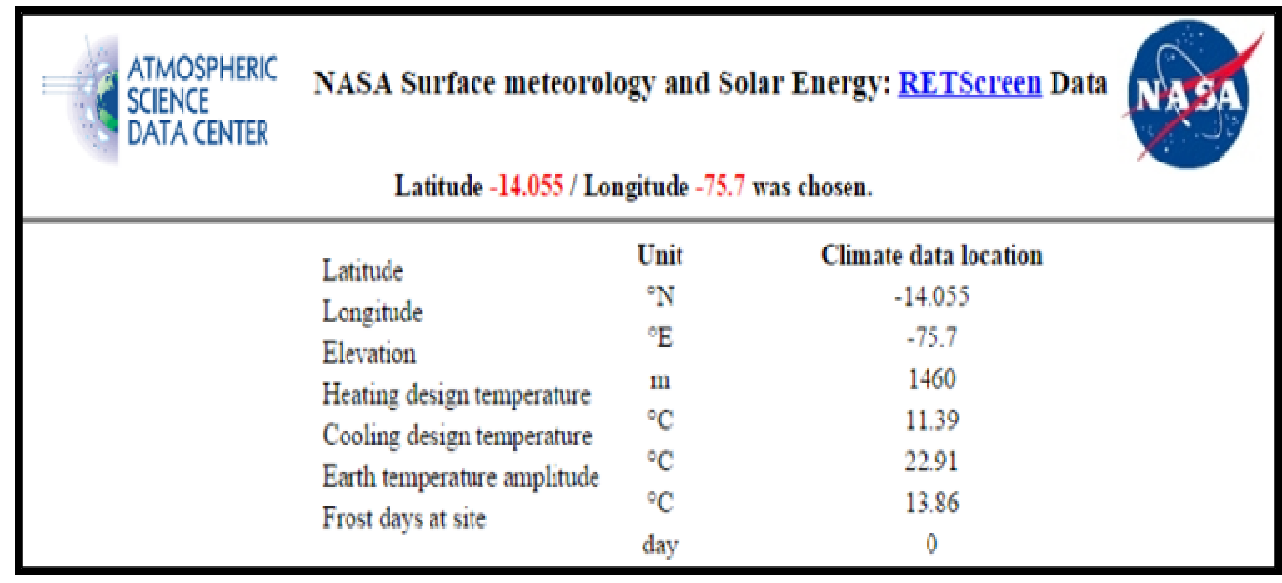

Figure 6: Entering the Coordinates of the Parcona District.

\begin{tabular}{|c|c|c|c|c|c|c|}
\hline Moeth & Air tremporatar & Relation buraidty & $\begin{array}{l}\text { Daik sdar } \\
\text { padotice - } \\
\text { bornodal }\end{array}$ & 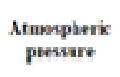 & Wind wet & $\begin{array}{c}\text { Evith } \\
\text { mupprature }\end{array}$ \\
\hline & ${ }^{+} \mathrm{C}$ & 4 & $\mathrm{kWh} m \mathrm{~m}$ & $\mathrm{kP}_{3}$ & $\mathrm{mt}$ & ${ }^{\alpha} \mathrm{C}$ \\
\hline hanery & 17.7 & $793 \%$ & 668 & $85: 9$ & 35 & 209 \\
\hline Fetnusy & 182 & $800 \%$ & 670 & 859 & 3.t & 210 \\
\hline March & 183 & 7864 & 464 & 858 & 33 & 211 \\
\hline Apel & 182 & $724 \%$ & 4.92 & 85.8 & 3,4 & 212 \\
\hline Mat & 178 & $586 \%$ & :12 & 859 & $\$ 6$ & 2018 \\
\hline hem & 168 & 5164 & 432 & 860 & 34 & 195 \\
\hline July & 164 & 4774 & $4 \$ 9$ & 860 & 40 & 191 \\
\hline Appast & 169 & $470 \%$ & 4.78 & $\$ 60$ & 34 & 202 \\
\hline Segatember & 173 & 49046 & 3.79 & 860 & 3.3 & 216 \\
\hline Octiles & 176 & 5396 & 699 & 859 & 3.7 & 227 \\
\hline Norewher & 17,4 & 6234 & 692 & 859 & 3.7 & 222 \\
\hline Decinsker & 17.6 & $712 \%$ & 3,00 & 854 & 3.6 & 217 \\
\hline Aละนม่ำ & 175 & $626 \%$ & 490 & 854 & 36 & 310 \\
\hline Mristidy 에 (m) & & & & & 100 & of \\
\hline
\end{tabular}

Figure 7: Solar Radiation Table.

The minimum solar radiation in the month of July of $4.29 \mathrm{~kW} \mathrm{~h} \mathrm{/} \mathrm{m} 2$ and maximum in the month of December of $7.00 \mathrm{~kW} \mathrm{~h} / \mathrm{m} 2$ is appreciated.

\section{Solar Panel Sizing}

Calculation of the total number of solar panels needed:

$$
N_{T}=\frac{L_{\text {mderit }}}{P_{M P P} * H P S_{\text {crit }} * P R}
$$

Where:

- $\left(L_{m d c r i t}\right)$ It is the average daily monthly consumption for the critical month (in this case, it is always the same [568.42 Wh/dia], since daily consumption is constant all year round)

- $\quad\left(P_{M P P}\right)$ The peak power of the module under standard conditions, we are using a $150 \mathrm{~W}$ peak power high efficiency monocrystalline panel. 
- $\quad\left(H P S_{\text {crit }}\right)$ They are the peak sun hours of the critical month calculated from the "Radiation Table", that is: Irradiation of the critical month (July) $=4.29$ HPS

- (PR) the global factor of operation that varies between 0.65 and 0.90 . We will use 0.90 by default.

$$
\begin{aligned}
& N_{T}=\frac{L_{\text {mdcrit }}}{P_{M P P} * H P S_{\text {crit }} * P R}=\frac{568.42}{150 * 4.29 * 0.90} \\
& N_{T}=0.98147 \approx 1
\end{aligned}
$$

Calculation of the number of photovoltaic panels in series and parallel (Considering the maximum panel voltage $\left.V_{\max }=18.90 \mathrm{~V}\right)$.

$$
\begin{aligned}
& N_{\text {SERIE }}=\frac{V_{B A T}}{V_{\max }}=\frac{12}{18.90}=0.635 \approx 1 \\
& N_{\text {PARALELO }}=\frac{N_{T}}{N_{S E R I E}}=1
\end{aligned}
$$

Considering the above formulas, to cover the required energy [568.42 Wh / day] a high efficiency $150 \mathrm{~W} 12 \mathrm{volt}$ monocrystalline photovoltaic panel is needed. The TS150M Panel is chosen for our design.

\section{Battery Sizing}

For our sizing, the nominal capacity of the battery is considered based on the maximum seasonal discharge $\left(C_{\text {ne }}\right)$.

$$
C_{n e}(W h)=\frac{L_{m d} * N}{P_{D \max e} * F_{C T}}
$$

Where:

- $\quad\left(P_{D \max e}\right)$ Maximum Seasonal Discharge Depth of $70 \%$.

- (N) Autonomy days numbers.

- $\quad\left(L_{m d}\right)$ Average daily energy consumption.

- $\quad\left(F_{C T}\right)$ Temperature Correction Factor.

$$
C_{n e}(\mathrm{Wh})=\frac{L_{\text {md }} * N}{P_{\text {Dmaxe }} * F_{C T}}=\frac{568.42 * 1}{0.7 * 1}=812.029 \mathrm{Wh}
$$

Expressing Nominal Capacity in Ah:

$$
C_{n e}(\mathrm{Ah})=\frac{C_{n e}(\mathrm{Wh})}{V_{B A T}}=\frac{812.029}{12}=67.67 \mathrm{Ah} \approx 65 \mathrm{Ah}
$$

For the choice of our energy accumulator we will consider a commercial value of the battery capacity of 65 Ah, that next lower value is chosen since it is considered margins of oversizing in all calculations and this will be compensated with the efficiency of the monitoring solar. For our design, the YUASA NP65-12 Battery is chosen, which supports deep discharges. 


\section{Regulator Sizing}

The maximum current that the regulator must withstand, at its input and output, will be calculated.

Input current:

$I_{\text {entrada }}=1.25 * I_{\text {MOD.CC }} * N_{P}$

Where:

- $\quad\left(I_{M O D, C C}\right)$ It is the unit current of the photovoltaic module in short-circuit conditions which will be found to avoid losses in performance is 8.45 Amps.

- $\quad\left(N_{P}\right)$ Number of photovoltaic panels in parallel.

- (1.25) It is the safety factor to avoid occasional damage to the regulator.

$I_{\text {entrada }}=1.25 * I_{M O D . C C} * N_{P}=1.25 * 8.45 * 1=10.56 \mathrm{~A}$

Output current:

$I_{\text {salida }}=\frac{1.25 * P_{D C}}{V_{B A T}}$

Where:

- $\quad\left(P_{D C}\right)$ Power of continuous loads.

- $\left(V_{B A T}\right)$ Battery Voltage.

$$
I_{\text {salida }}=\frac{1.25 * P_{D C}}{V_{B A T}}=\frac{1.25 * 51}{12}=5.31 \mathrm{~A}
$$

The regulator should withstand a current of at least 10.56 At its input and 5.31 A at its output. For our design we use the commercial value of $20 \mathrm{~A}$ and 12V, the model CMTP02 MPPT solar charger charger is chosen, this MPPT type solar charger regulator can increase efficiency by $10 \%-30 \%$.

\section{Sizing of the LED Lantern}

For our design of public lighting we will use a 30W 12VDC LED lantern which must have a degree of protection IP65 (Strong protection against dust and water jets). For this design we will use Model FH-LD30W LED Lantern.

\section{Sizing of the Solar Tracking System}

Our public lighting design will implement a solar tracking of one degree of freedom, because the maximum variation between Sun and panel occurs in azimuth of the earth, the variation in elevation is neglected as it is considered of little impact in terms of energy and is more expensive. implementation costs. However, the elevation is done manually every 6 months for each winter and summer season, or can be set in the middle, for both seasons. We will have a sensor that will tell us which is the brightest point in the sky to be aimed at. 


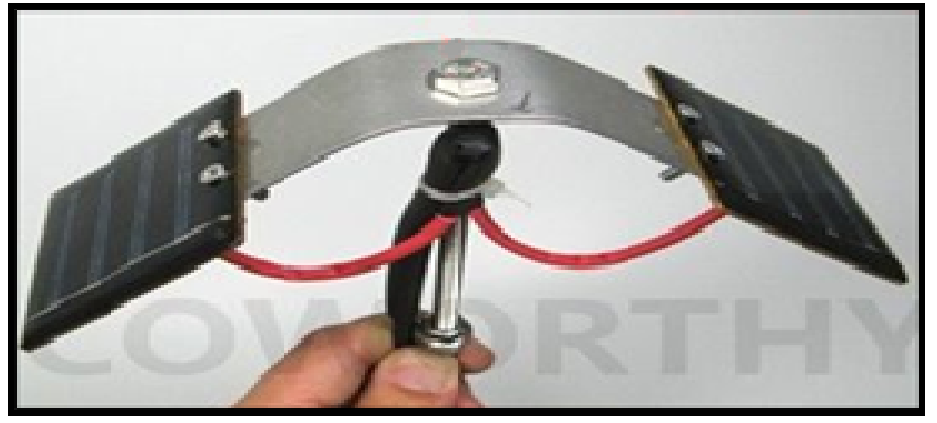

Figure 8: Umbrella Detector.

An umbrella type light sensor is chosen, which is composed of two Epoxy silicon cells on a stainless steel metal structure allowing to adjust the steering angle and calibrate the orientation, a metal structure. Using an Electric linear actuator allows us to position our solar panel where the sensor indicates.

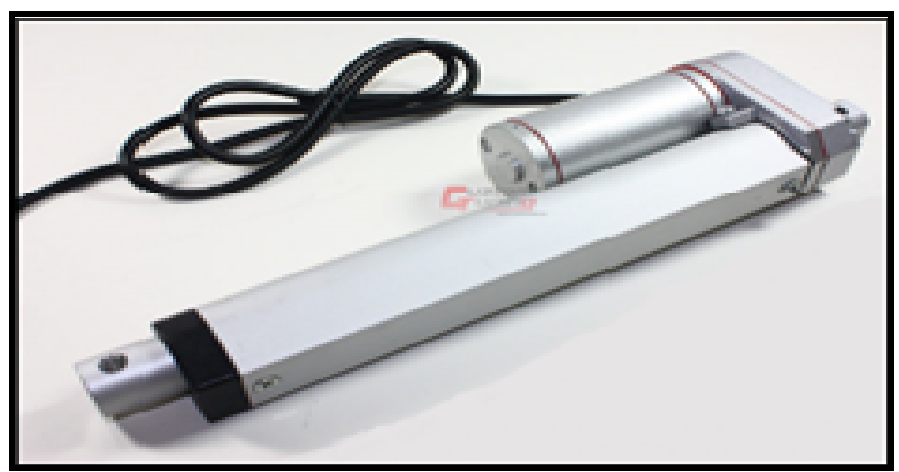

Figure 9: Electric Linear Actuator.

\section{System Controller Design}

A custom controller design is made based on the PIC18F4550 microcontroller, which will carry out an autonomous control of the system and send the information from the solar cells, current sensors, lumen depreciation sensors and motion sensor to a reception stage which can be processed and viewed in a graphical interface.

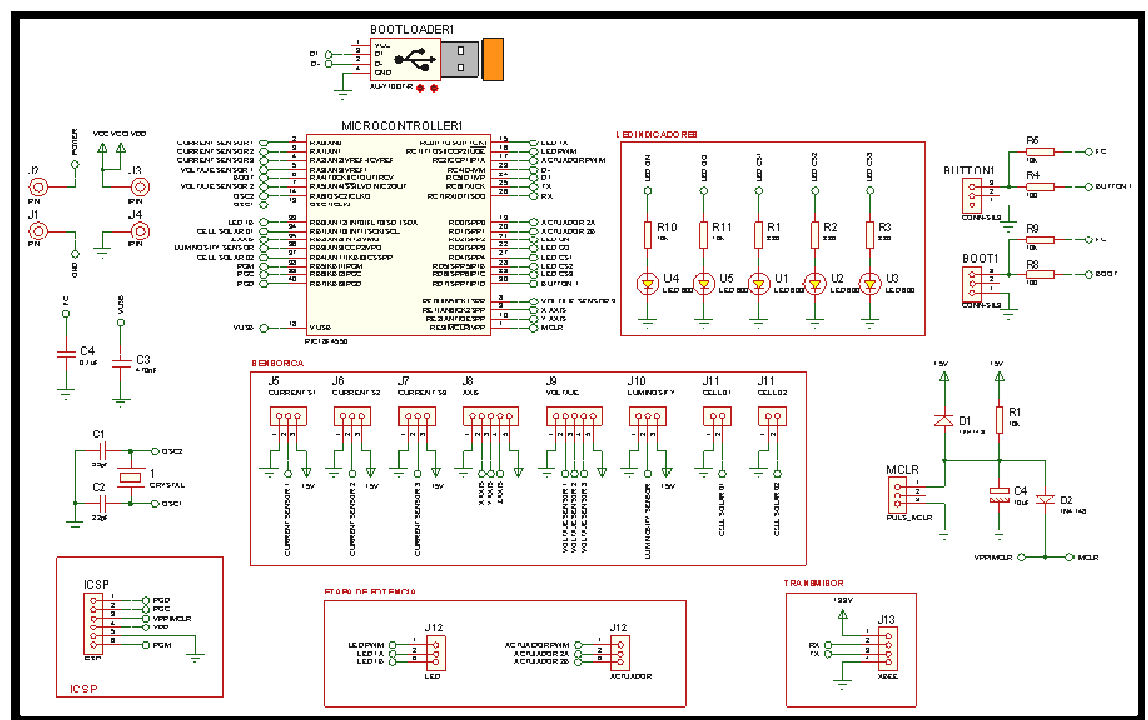

Figure 9: Controller Layout with PIC18F4550. 
This design will control two power stages, the first being the LED lantern which, through the generation of PWM, we can vary the light intensity according to the needs and the second the electric linear actuator that we will vary the speed of the motor, managing to position our panel. with the greatest precision that we request.

The PIC18F4550 microcontroller allows us to implement a bootloader through the USB port [1], facilitating the download of programming, making the adjustments that carry the calibration quickly and efficiently.

\section{Design of the Graphical Interface}

A monitoring interface is designed in LabView, which is a platform and development environment to design systems, with a graphic visual programming language (G language).

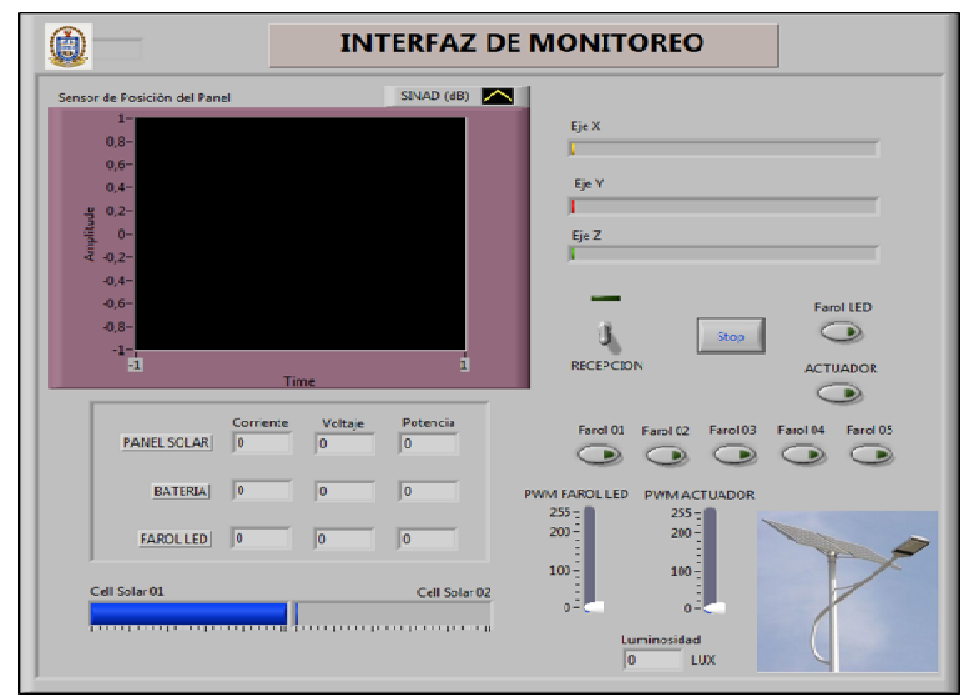

Figure 10: Monitoring Interface.

In our monitoring interface, all the sensors of our public lighting design are displayed, such as the motion sensor that allows us to visualize the position of the solar panel and the disturbances that could appear from gusts of winds. With the current sensors we obtain readings of the panel, battery and the LED lamp in real time. We can vary the intensity of the lantern and the speed of the actuator motor. The light intensity is visualized by means of a luminosity sensor and finally the lantern to be evaluated is selected.

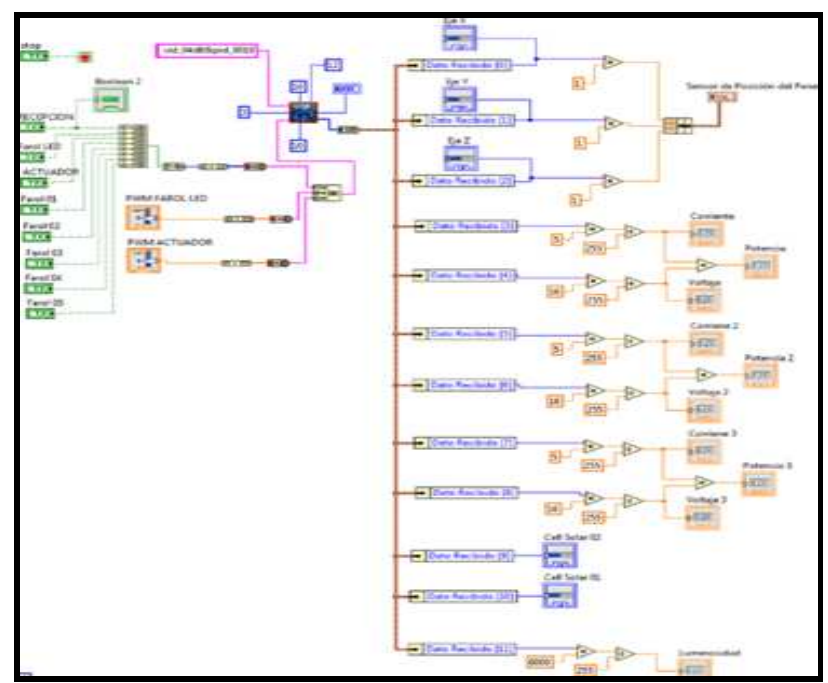

Figure 11: Programming the Monitoring Interface. 
In the programming of the monitoring interface, the reception of 10 Bytes is visualized to visualize the readings of the sensors and he sent 3 Bytes which are for control and selection.

\section{SIMULATION IN LABVIEW}

Our prototype of public lighting in the day the solar panel provides the necessary energy to charge our battery obtaining voltage readings and charging currents. We can regulate the speed of the actuator by fine-tuning the solar panel position degrees.

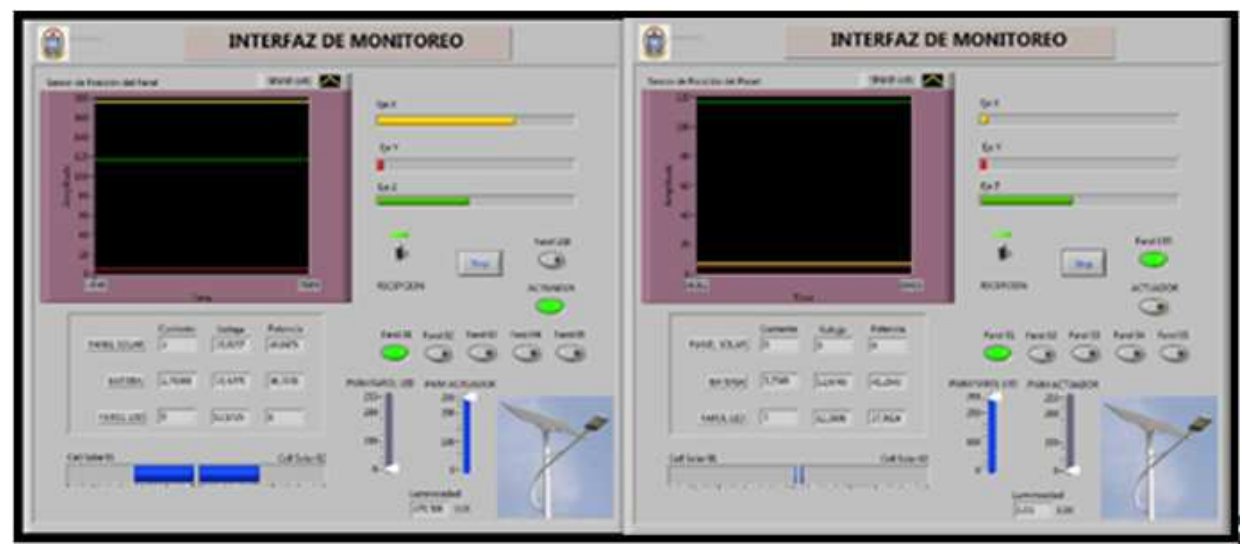

Figure 12: Day - Night Operation.

It can be seen that the bars of the position solar cells are homogeneous, this indicating that it is pointing to the greatest amount of radiation, if these bars vary, our actuator will be activated and positioned on the panel to obtain the values of the cells again equal.

When the sun sets, the LED lantern is turned on, we obtain current and operating voltage readings, we can vary the intensity of light if required at the time.

\section{RESULTS}

The results obtained in our research carried out in the real-time simulation of the PIC18F4550 controller with the Proteus ISIS software with the monitoring interface made in LabVIEW gives us the behavior of our system both in daytime mode (Charging of energy accumulators, panel solar - battery) and night mode (accumulator discharge, battery - led lantern), obtaining values of amperage, voltage and power of the system for optimal operation.

\section{CONCLUSIONS}

- It is concluded that we can obtain enough solar energy in the Parcona district throughout the year to power an LED lantern for 12 hours of daily operation.

- Through the sensor, the capture and energy consumption can be monitored, in which the readings are interpreted that will allow us to make the necessary adjustments to obtain the maximum efficiency of the system.

- The ideal panels to implement the system are monocrystalline type panels, due to their symmetrical arrangement, allowing greater efficiency between $15 \%$ and $18 \%$. 
- It is recommended to increase the number of days of battery life according to the maximum seasonal discharge if required.

- Make speed adjustments of the linear actuator to obtain desired degrees of position of the panel with respect to the Sun, consider manufacturing a rigid structure with the ability to resist winds of up to $140 \mathrm{~km} / \mathrm{h}$.

- When choosing the solar panels to be used in the project, it must be taken into account that these must be the largest, since with these a greater efficiency is obtained than with a smaller one.

\section{REFERENCES}

1. García Breijo, Eduardo. “Compilador C CCS y Simulador PROTEUS para Microcontroladores PIC”, 2da edición. España, Marcombo, 2009.

2. Jean Acquatella, "Energía y cambio climático: oportunidades para una política energética integrada en América Latina y el Caribe”, Naciones Unidas, Santiago de Chile 2008.

3. eosweb.larc.nasa.gov [Internet]. USA: Centro de investigación Langley; 2014 [actualizado 21 Feb 2015]. Disponible en: https://eosweb.larc.nasa.gov/cgi-bin/sse/retscreen.cgi?email=rets\%40nrcan.gc.ca\&step=1\&lat=-14.0549\&lon=$75.6998 \&$ submit $=$ Submit

4. Lluís Prat Viñas. Dimensionado de Sistemas Fotovoltaicos [Internet]. Universitat Politécnica de Catalunya. Barcelona, España; Disponible en:

5. http://ocw.upc.edu/sites/default/files/materials/15014928/4b.dimensionado_sistema_fotovoltaico-4826.pdf 
